\title{
Neuropsychiatric Disorders in Egyptian Children's After Divorcing
}

\author{
Abdel-Fattah HMM* \\ Neuropsychiatry Department, El. Abbassia Mental Hospital, Egypt
}

\begin{abstract}
Background and Objective: In Egypt, as a result of the noticeable rise in divorce rates and the increase in the number of divorce children in a way that represents a danger to the public future, and because of the Personal Status Law that deprives the father of hosting or cohabitation or sharing custody with his children after the divorce.
\end{abstract}

Methods: Information was collected about the extent of the impact of the deprivation and absence of the father on the children of divorce from previous research And the Central Agency for Public Mobilization and Statistics and the Egyptian government portal.

Results: The data and results revealed that because of this random and unscientific law, these children are exposed to a great danger at all levels of development, which constitutes a major disaster.

Conclusion: The results indicate the urgent need for rapid legislative amendments aimed at implementing the shared care system and its owners and the father's hosting and coexistence with his children for the healthy development children of divorce in Egypt, in order to preserve the strength of the fabric of society and the solidity of the Egyptian state.

KEYWORDS: Egypt; Divorce; Child; Depravation; Law; Custody

\section{INTRODUCTION}

Parental separation affects a child's development. Early parental divorce (during primary school) has been associated with greater behavior problems within the kid [1]. While divorce later in childhood or adolescence may dampen academic performance. Fatherless Children tend to suffer greater emotional and social difficulties than others do. Father absence mainly results from parental divorce and separation [2].

An increase within the divorce rate in Egypt (Figure 1) and increases the divorce Percentage, by Marriage Duration which become shorter (Figure 2). Have introduced the Absent Egyptian Father that defines as an ongoing emotional, social or spiritual deficit within the children's and their fathers after divorced, this deficit often leaves anger and pain, extreme behaviors, addictions or obsessions, inner sense of being lost and incomplete, lacking assurance and self-confidence. In the Egyptian personal law, the father is prohibited from hosting his children or living with them after the divorce. he is only allowed to determine them in a very public place like clubs for 3 hours every week [3] and if he leaves them from this club, it is considered against the law of kidnapping and will cause the daddy to be imprisoned. During this situation, the daddy after the divorce is taken into account unjust, this law was passed in 2000 to convey material gains to women at the expense of the child's psychological development and basic needs, which caused many health and psychological crises and disasters for this generation of divorce children, including per the international scientific references mentioned (Figures 3 ).

a) $63 \%$ of youth suicides are from fatherless homes [4].

b) $85 \%$ of all children who show behavior disorders come from fatherless homes [5].
Quick Response Code:

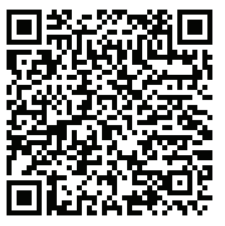

Address for correspondence: Hesham Maged Mohammed Abdelfatah Neuropsychiatry Doctor, International Scholar, Egyptian Ministry of Health, ElAbbassia Mental Hospital, Egypt

Received: June 11, $2021 \quad$ Published: June 21, 2021

How to cite this article: Abdel-Fattah HMM. Neuropsychiatric Disorders in Egyptian Children's After Divorcing. 2021- 3(3) OAJBS.ID.000296. DOI: 10.38125/OAJBS.000296 
c) $80 \%$ of rapist motivated by displaced anger comes from fatherless homes [6].

d) $71 \%$ of all high school dropouts come from fatherless homes [7].

e) $\quad 5-75 \%$ of all adolescent patients in Drug's abuse centers come from fatherless homes [8].

f) $70 \%$ of youths in state-operated institutions come from fatherless homes [9].

g) $85 \%$ of all youths in prison come from fatherless homes [10].

h) Absent Father increases the risk of children abusing by 3 times [11].

i) Children living in female-headed homes with no spouse present had a poverty rate of $47.6 \%$. This was over four times the rate for children living in married-couple families [12].

j) Men who grew up with absent fathers were more likely to become absent fathers. They also found that women who grew up with absent fathers are more likely to have children with absent fathers [13].

k) Father absence increased the risk of infant mortality, and that the mortality rate for infants within the first 28 days of life is four times higher for those with absent fathers than those with involved fathers [14]. l) Individuals from father-absent homes are $279 \%$ more likely to carry guns and deal drugs than peers living with their fathers [15].

m) Adolescent boys with absent fathers are more likely to engage in delinquency than those who are present [16].

n) Children in father-absent homes suffer 2 times of obesity than are non-obese children [17].

o) Fatherless girls have been found to be at risk for teenage pregnancy [18].

p) Early maturing fatherless boys are at risk for sexual promiscuity [19].

q) Cinderella Effect, which refers to the observation that stepchildren are at a dramatically increased risk of physical abuse and homicide than children living with their biological parents [20].

r) Presence of a stepfather is not compensating to the disadvantages of a biological father being absent. it can cause an even bigger negative effect on children [21].

s) Early maturing fatherless girls have been found to be at risk for giving birth to low-birth-weight infants.

t) The child's estrangement, manifest itself as fear, disrespect, or hostility toward the distant father, and may extend to additional relatives or parties.

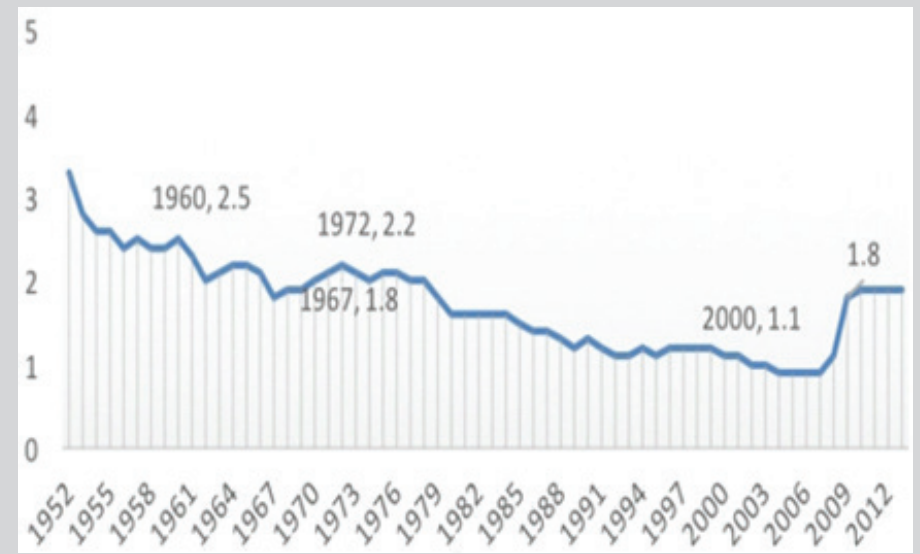

Figure 1: Divorce rates in Egypt.

Source: Population Situation Analysis, Egypt 2016.

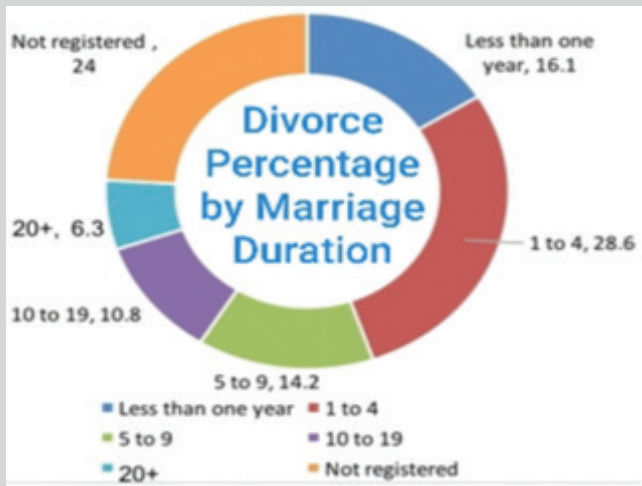

Figure 2: Distribution of divorce percentage, by marriage duration.

Source: Population Situation Analysis, Egypt 2016. 


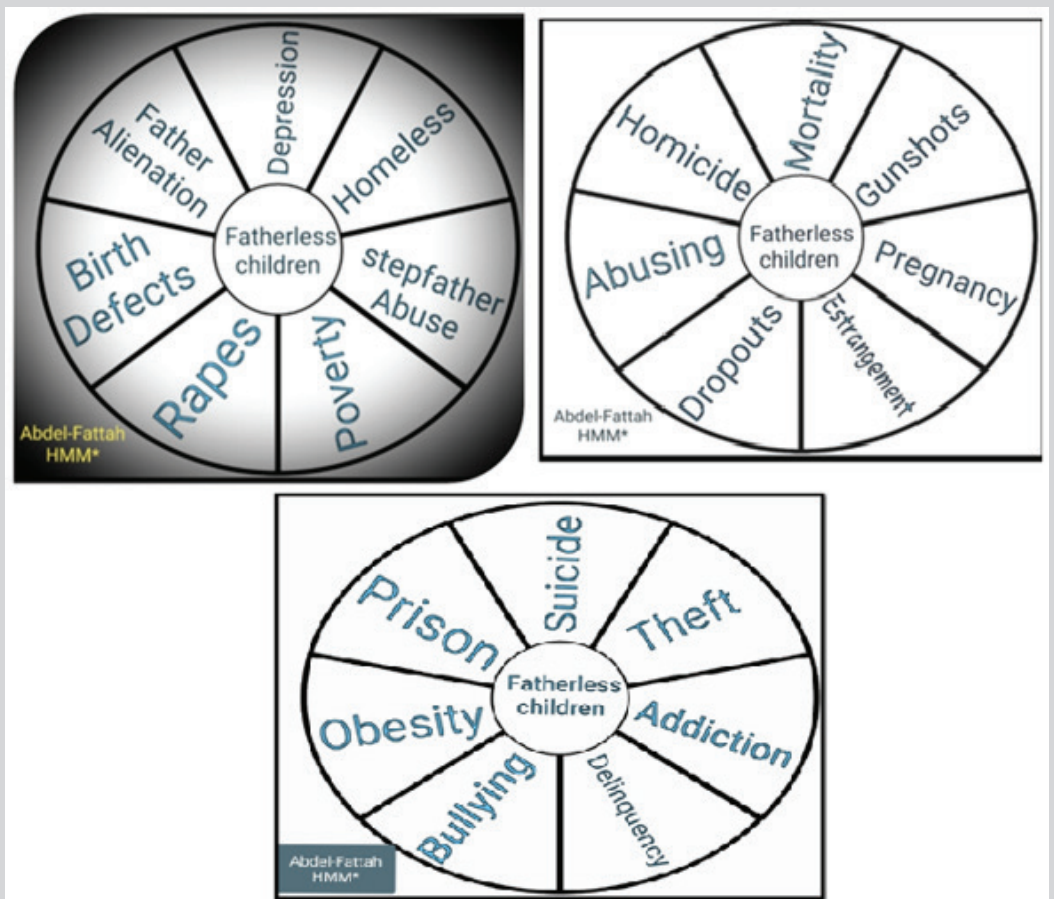

Figure 3: Neuropsychiatric disorders in Fatherless children.

\section{CONCLUSION}

The Egyptian legislator and the must make quick amendments to the Personal Status Law that allow the Father and his family, cohabitation and hosting of the divorced child without any disturbance to the child's activities at the academic, sports, social and familial levels, by this way he can achieving the healthy psychological and organic development and we can maintaining family cohesion even after separation and controlling this massive disorders in Egyptian children's to protect their human rights.

\section{DATA AVAILABILITY STATEMENT}

The original contributions generated for the study are included within the article/supplementary materials, further inquiries are often directed to the corresponding author.

\section{CONFLICT OF INTEREST}

The author declare that the research was conducted within the absence of any commercial or financial relationships that might be construed as a possible conflict of interest.

\section{ACKNOWLEDGMENT}

Many thanks to my lovely family, my children's (Mido and Menna) with special thanks to my favorite place (El- Abbassia Mental Hospital).

\section{REFERENCES}

1. Flouri E, Narayanan MK, Midouhas E (2015) The cross-lagged relationship between father absence and child problem behaviour in the early years. Pubmed 41(6): 1090-1097.

2. Amato, Paul R (2010) Research on divorce: Continuing trends and new developments. The Journal of Family Medicine \& Review 72(3): 650-666.

3. US Dept. Of Health/Census.

4. Criminal justice and behavior.

5. National principal's association report.

6. Rainbows for all god's children.
7. (1988) U.S. Department of Justice.

8. Fulton Co. Department of Correction, Georgia, Texas, USA.

9. Bendheim-thomas center for research on child wellbeing and social indicators survey center (2010).

10. (2012) Information on poverty and income statistics: A summary of 2012 current population survey data.

11. Pougnet E, Serbin LA, Stack DM, Ledingham JE, Schwartzman AE (2012) The intergenerational continuity of fathers' absence in a socioeconomically disadvantaged sample. Journal of Marriage and Family 74(3): 540-555.

12. Alio AP, Mbah AK, Kornosky JL, Wathington D, Marty PJ, et al. (2011) Assessing the impact of paternal involvement on Racial/Ethnic disparities in infant mortality rates. Journal of Community Health 36(1): 63-68.

13. Allen AN, Lo CC (2012) Drugs, guns and disadvantaged youths: Cooccuring behavior and the code of the street. Crime \& Delinquency 58(6): 932-953.

14. Cobb-Clark DA, Tekin E (2014) The national longitudinal study of adolescent health

15. National longitudinal survey of youth.

16. Udry J Richard, Cliquet R L (1982) Across-cultural examination of the relationship between ages at menarche, marriage and first birth. Demography 19(1):53-63.

17. Cota-RS, Neiss M, Rowe DC (2002) The Role of Puberty in Violent and Nonviolent Delinquency among Anglo American, Mexican American and African American Boys. Journal of Adolescent Research. 17(4): 364-376.

18. Daly M, Wilson M (1999) The truth about cinderella: A Darwinian view of parental love. New Haven, Conn. Yale University Press, USA.

19. Mendle J, Harden KP, Turkheimer E, Van HCA, Onofrio DBM, et al. (2009) Associations between father absence and age of first sexual intercourse. Child Development 80(5):1463-1480.

20. Scholl T, Hediger M, Vasilenko P, Ances I, Smith W, et al. (1989) Effects of early maturation on fetal growth. Annals of Human Biology 16 (4): 335-345.

21. Lorandos D, Baker A, Campbell T, Freeman B, Lowrance HMJD (2013) Parental alienation: The handbook for mental health and legal professionals. Springfield Il (edn), Charles C Thomas Publisher. p. 550. 